\title{
RESUMO
}

DIREITO

V.8・N.1 • Novembro 2019 - Fevereiro 2020

ISSN Digital: 2316-381X

ISSN Impresso: 2316-3321

DOI: 10.17564/2316-381X.2019v8n1p143-160
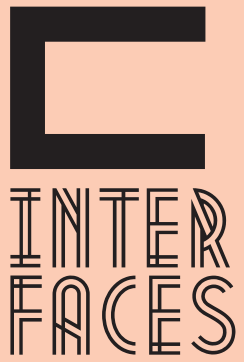

CIENTÍFICAS

\section{DEMISSÕES DISCRIMINATÓRIAS DE SOROPOSITIVOS: UMA ANÁLISE AO POSICIONAMENTO DOS RELATORES DA PRIMEIRA TURMA DO TRT6 A PARTIR DO CONTRAPONTO AOS PRINCÍPIOS CONSTITUCIONAIS}

DISCRIMINATORY DEMONSIONS OF SOROPOSITIVES: AN ANALYSIS OF THE POSITIONING OF RAPPORTEURS OF THE FIRST TRT6 CLASS FROM THE APPLICABILITY OF CONSTITUTIONAL PRINCIPLES

DESPIDOS DISCRIMINATORIOS DE SEROPOSITIVOS: UN ANÁLISIS DE LA POSICIÓN DE LOS PRIMEROS RELATORES DEL TRT6 DESDE EL CONTRAPUNTO HASTA LOS PRINCIPIOS CONSTITUCIONALES
Gabriela Maria Farias de Carvalho ${ }^{1}$ João Claudio Carneiro de Carvalho
Este artigo visa o estudo dos casos de demissão de trabalhadores soropositivos, no que tange aos seus direitos trabalhistas, por meio de uma análise de decisão que resolve casos análogos no Tribunal Regional do Trabalho da sexta região. Retrata como acontece na prática essas demissões discriminatórias, quais os argumentos usados pelos gestores ao descobrirem que o empregado é portador da doença, a exigência do exame de maneira ilegal e como está à regulamentação e o tratamento mais aplicado atualmente para essas situações no âmbito do TRT6. Os portadores do vírus devem ser tratados de maneira igualitária como prevê nossa Constituição Federal e devem, acima de tudo, receber o tratamento isonômico dos demais trabalhadores. Isso porque, existe proteção jurídica para os casos de descumprimento da lei. Falta ainda, uma melhor aplicabilidade da legislação, a devida fiscalização, aliada a informação adequada com relação aos direitos conferidos aos portadores da doença. Se faz necessário ainda a quebra de velhos tabus e preconceitos com o portador do vírus com o devido tratamento, adequando a seu grau de evolução da doença terá perfeitas condições de atuar no mercado de trabalho assim como qualquer outro indivíduo.

\section{PALAVRAS-CHAVE}

Tribunal Regional do Trabalho da $6^{\text {a }}$ Região. Legislador. Direitos Fundamentais. Demissão. Trabalhadores. Soropositivos. 


\section{ABSTRACT}

This article aims to study the cases of dismissal of seropositive workers regarding their labor rights, through a decision analysis that resolves similar cases in the Regional Labor Court of the sixth region. It portrays, as in practice, these discriminatory dismissals, the arguments used by managers to discover that the employee is the carrier of the disease, the requirement of the examination in an unlawful manner, and how is the regulation and treatment currently applied to these situations in the TRT6. The virus carriers must be treated equally as provided for in our Federal Constitution, and must above all receive the isonomic treatment of the other workers. That is because, there is legal protection for cases of non-compliance with the law. There is still a need for better enforcement of legislation, due monitoring, and adequate information regarding the rights granted to patients with the disease. It is still necessary to break old taboos and prejudices. The person carrying the virus with due treatment, adjusting to his degree of evolution of the disease will have perfect conditions to work in the labor market as any other individual.

\section{KEYWORDS}

Regional Labor Court of the 6th Region. Legislator. Fundamental Rights. Dismissal. Workers. Seropositive.

\section{RESUMEN}

Este artículo tiene como objetivo estudiar los casos de despido de trabajadores seropositivos, en relación con sus derechos laborales, a través de un análisis de decisiones que resuelva casos similares en el Tribunal Laboral Regional de la sexta región. Describe cómo ocurren estos despidos discriminatorios en la práctica, cuáles son los argumentos utilizados por los gerentes cuando descubren que el empleado es portador de la enfermedad, el requisito del examen ilegalmente y cómo se aplica la regulación y el tratamiento actual a estas situaciones dentro del alcance de la ley. TRT6. Los portadores del virus deben ser tratados por igual, según lo dispuesto en nuestra Constitución Federal, y sobre todo recibir el tratamiento isonómico de otros trabajadores. Esto se debe a que existe protección legal para los casos de incumplimiento de la ley. Todavía falta una mejor aplicabilidad de la legislación, la debida supervisión, junto con información adecuada sobre los derechos otorgados a los pacientes con la enfermedad. Todavía es necesario romper viejos tabúes y prejuicios con el portador del virus con el tratamiento adecuado, adaptándose a su grado de evolución de la enfermedad tendrá condiciones perfectas para trabajar en el mercado laboral como cualquier otro individuo. 


\section{PALABRAS CLAVE}

Tribunal Laboral Regional de la 6ta Región. Legislador. Derechos Fundamentales. Despido. Trabajadores. Seropositivo.

\section{INTRODUÇ̄̃̃O}

A opção pela abordagem do tema proposto para o presente artigo científico se dá pela perspectiva da aplicabilidade de princípios constitucionais, além de outros elementos normativos na construção do voto do Relator da primeira turma do tribunal. Nesse caso, a decisão objeto do trabalho aqui analisada envolve demissões de trabalhadores portadores do vírus da AIDS, decisão esta, direcionada pelo Tribunal Regional do Trabalho da $6^{\text {a }}$ Região.

A construção do presente artigo ocorreu do estudo de como vem sendo resolvidos esses dilemas trabaIhistas de cunho discriminatório no âmbito deste tribunal, onde mesmo após inúmeros debates relacionados com o tema, ainda se percebe o grande número de demandas que demonstram a maneira inadequada com que são tratados os trabalhadores afetados com a doença ao tempo do desligamento nas empresas.

Ocorre que, por diversas vezes o descumprimento de leis que tratam do assunto, assim como o desrespeito a alguns dos princípios constitucionais norteadores e integrantes do ordenamento jurídico brasileiro, os quais, limitam a problemática aqui abordada, acarretam graves danos a vida do empregado, principalmente se for levado em consideração a maneira humilhante com que esse público específico é obrigado a passar ao "término" de seus contratos de trabalho.

Com "análise do discurso" do Relator na decisão, pretende-se aqui, reforçar o direito das pessoas portadoras de doenças graves como a AIDS e a possibilidade de seguir com suas vidas normalmente, inclusive dentro do mercado de trabalho. Entende-se, que estando controlada a doença, de nada impede que o indivíduo acometido desse vírus, trabalhe e tenha uma vida digna como qualquer outro, este também foi o direcionamento do respectivo voto da primeira turma. Até porque, como anteriormente mencionado, é garantido constitucionalmente a concessão de tais oportunidades. A discriminação pelo fato de ser acometido de doença grave, fere diretamente a um dos mais significativos princípios incluídos pela Constituição Federal de 1988, que é o da dignidade da pessoa humana.

A metodologia aplicada ao presente artigo é a análise do discurso, tomando como referência o direcionamento dado durante o voto, baseando-se primordialmente nos conceitos jurídicos envolvidos nos "princípios da igualdade”, "dignidade da pessoa humana", "princípio da função social”, "da busca do pleno emprego", "direito de ir e vir", "direito à liberdade”, "individualidade”, "da inviolabilidade à intimidade", "da privacidade", “da honra”, e da "imagem”.

Foi utilizado como objeto o inteiro teor do voto, os critérios para utilização de precedentes, além da aplicabilidade de princípios constitucionais, lei específica para o caso, outros entendimentos de autoridades competentes, súmulas, e recomendações da Organização Internacional do Trabalho (OIT). 
Negar a oportunidade de trabalho, além de todos os danos acarretados a vida privada do trabalhador, ainda pode trazer grandes prejuízos aos cofres públicos do Estado. Uma vez que, não podendo contribuir para o próprio sustento, o trabalhador vai precisar recorrer aos hospitais públicos para dar continuidade ao seu tratamento contra o vírus, já que não possuirá mais a sua renda para fazê-lo de outra forma.

A decisão do TRT6, que além de resolver o conflito de interesses das partes, ainda proporcionou algumas quebras de paradigmas na hora da aplicação do direito, assegurando a igualdade a todos. Assim, pretende-se destrinchar o entendimento deste tribunal, com o intuito maior de enfatizar a aplicação dos princípios constitucionais aplicados na decisão de cunho trabalhista, na garantia dos direitos de todos.

Com o estudo detalhado da decisão, entende-se que a primeira turma do tribunal, pretendeu conferir certeza absoluta aos direitos do trabalhador portador do vírus, devolvendo-o ao seu posto de trabalho fazendo com que o empregador possibilite meios adequados e igualitários para todos que prestem serviço naquele local, tomando assim uma decisão baseada na mais ampla justiça.

\section{HISTÓRIA, PROBLEMÁTICA E INCLUSÃO - APLICABILIDADE DO PRINCÍPIO DA FUNÇÃO SOCIAL NO VOTO DO RELATOR}

Montagnier (2008), diz que em 1981 foram notificados os primeiros casos de Aids (como a doença é conhecida), uma doença causadora de Imunodeficiência severa e afetava em sua maioria das vezes homens gays. Posteriormente pesquisadores alemães conseguiram isolar o vírus que causava a doença e após mais de três décadas o HIV continua sendo uma doença sem cura, que causou a morte de mais de 30 milhões de indivíduos.

Apesar dos grandes e importantes avanços no que se refere aos tratamentos e na melhoria da qualidade de vida dos portadores da doença, o departamento das nações unidas voltados para a doença, alerta para que há mais de 34 milhões de pessoas convivendo com a doença no mundo. Inclusive, em alguns países se pode encontrar pacientes convivendo sem nenhum tratamento.

Atualmente no Brasil já existe um certo controle dos sintomas da doença com o tratamento e aplicação de forma gratuita garantida para os portadores da doença, garantindo assim o direito à vida.

Em casos de tratamento no âmbito privado alguns planos de saúde ainda se negavam a autorizar o tratamento com cobertura completa pelos convênios, o que foi bastante discutido em fóruns do tema e hoje sabe-se que essa cobertura está bem menos burocrática (ou deveria ser), e caso o doente ainda encontre dificuldades na liberação do tratamento devido, deve procurar seus direitos perante a lei. $\mathrm{Na}$ verdade, esse é assunto para outra oportunidade.

Abaixo podemos verificar legislação proposta pela Declaração dos Direitos Fundamentais da Pessoa Portadora do Vírus da AIDS, a qual, também serve como parâmetro utilizado pelo TRT6, na tomada de decisão.

De maneira a tirar qualquer dúvida com relação ao tratamento adequado aos portadores da doença, a declaração vem fortalecer ainda mais e de maneira detalhista a posição que deve ser tomada mediante conflitos que envolvam esse tipo de discriminação. 
III - Todo portador do vírus da aids tem direito à assistência e ao tratamento, dados sem qualquer restrição, garantindo sua melhor qualidade de vida.

IV - Nenhum portador do vírus será submetido a isolamento, quarentena ou qualquer tipo de discriminação.

VI - Todo portador do vírus da aids tem direito à participação em todos os aspectos da vida social [...].

$\mathrm{X}$ - Todo portador do vírus tem direito a comunicar apenas às pessoas que deseja seu estado de saúde e o resultado dos seus testes.

XI - Toda pessoa com HIV/aids tem direito à continuação de sua vida civil, profissional, sexual e afetiva. Nenhuma ação poderá restringir seus direitos completos à cidadania. (BRASIL, 2014, p. 1. Grifo nosso).

Além das garantias fundamentais, disponibilizadas por meio de nossa constituição o portador do vírus ainda goza de legislações específicas, adequadas a aplicação do caso. A legislação fundamental contribuiu para o encaminhamento e melhor direcionamento de uma linha de raciocínio presentes na decisão e no entendimento dos Relatores.

Isto irá se tornar um problema enorme em todo o mundo, que qualquer insight de qualquer dimensão pode ser de imensa ajuda. Só na América, neste ano, quatrocentas mil pessoas estão infectadas pela AIDS, e a cada ano o número dobrará. No próximo ano serão 800 mil pessoas, e então um milhão e seiscentas mil pessoas; e isto continuará - dobrando. Apenas neste ano a América necessitará de 500 milhões de dólares para socorrer estas pessoas, e assim mesmo não há muita esperança deles sobreviverem. (JAIN, 1985, p. 432).

Como retrata o texto do pensador Chandra Mohan Jain (Osho), em sua colocação que ou nos adequamos ao rumo que a sociedade está tomando ou perderemos oportunidade de crescimento econômico, no que diz respeito ao aproveitamento desse "material" humano.

Com o passar dos anos, foi trazida a baila a questão da inclusão social de todos os povos e a ampla discussão acerca da matéria aqui em análise.

A inclusão dos portadores do vírus ao mercado de trabalho é uma problemática social, que perdura até hoje.

Como podemos verificar, com uma análise mais detalhada da situação de saúde popular, ficou notório que não era uma questão de bondade e sim necessidade das empresas em incluir os trabalhadores portadores de moléstia grave, tal como a AIDS.

Conforme relato, a recorrente insurge-se contra o indeferimento do pedido de reintegração ao emprego ou indenização compensatória, bem como do pleito de indenização por dano moral, alegando que, quando foi dispensado, encontrava-se em tratamento de saúde, por ser portador do vírus HIV e a dispensa foi motivada por razões discriminatórias, em vista da própria condição de saúde, evidenciando-se a mácula à honra e dignidade, valores que encontram tutela na Lei $n .^{\circ}$ que cuida da reabilitação de pessoa deficiente, conceituado como tal aquela cuja possibilidade de obter e conservar um emprego ade- 
quado de nele progredir fique substancialmente reduzido por causa de uma doença devidamente reconhecido e na Convenção n. ${ }^{159}$, da OIT. (TEIXEIRA, 2018, p. 3).

Nessa seara, foram acontecendo as devidas mudanças na perspectiva das empresas e cada vez mais as decisões judiciais foram tomando um rumo garantidor de tais princípios. Conferindo além de outros princípios, o da função social oculto na discussão e decisão do voto em análise.

\section{OS DIREITOS FUNDAMENTAIS NA ÓPTICA DO RELATOR.}

Os direitos fundamentais garantidos pela Constituição Federal da República de 1988, se dá em seus artigos do 5 ao 17, os quais, protegem o indivíduo do Estado e são uma adaptação dos Direitos Humanos à realidade social e cultural do Brasil. Listam em seu estudo direitos individuais, sociais, nacionais, políticos e partidos políticos.

Em sua essência, esses direitos possuem algumas características como a limitabilidade, universalidade, irrenunciáveis e imprescritíveis. Neste viés, não existe ao menos a possibilidade de renúncia de direitos, sendo esses de caráter irrenunciáveis.

Logo, no início de uma leitura mais detalhada do voto, pode-se verificar na argumentação do relator, que houve uma preocupação em divergir com o juízo de primeiro grau, a médica que na decisão proferida não foi concedido os direitos fundamentais do ora Reclamante.

Com a devida vênia, divirjo.

Relatou que é portador de HIV e também se encontrava com hérnia umbilical no ato da demissão ilegal, tendo inclusive deixado de fazer a cirurgia da hérnia umbilical em razão de a Reclamada ter cancelado o plano de saúde.

Em consequência dos fatos narrados, requereu o reconhecimento do direito à estabilidade no emprego ou indenização substitutiva, bem como indenização por danos morais, por ter sido dispensada por motivo discriminatório. (TEIXEIRA, 2018, p. 2).

Observa-se, que ao contrário do que foi informado na sentença, a doença do trabalhador naquela ocasião não estava controlada, o empregado precisava utilizar-se das benfeitorias que era estar trabalhando com o benefício de um plano de saúde para fazer o tratamento adequado e que, sabendo de sua fragilidade momentânea, o empregado optou pela demissão.

Importante frisar, que os direitos fundamentais são baseados nos direitos humanos, garantidores da liberdade, igualdade, educação, direito a vida e a segurança. Assim, o relator ao discordar da opinião do juízo de primeiro grau, tomou uma decisão de cunho assertivo.

Ao efetivar essa demissão o empregador estaria tirando do trabalhador, doente e frágil o direto a vida e a saúde, acelerando ainda mais a piora de seu quadro. Neste sentido optou por conceder o reconhecimento do direto de estabilidade no emprego, entendendo que não haveria motivos para distinção entre um trabalhador com outra doença grave e o acometido pelo HIV. 


\section{SÚMULA 443 DO TST E CONVENÇÃO 111, DA OIT - RELEVÂNCIA DO PRINCÍPIO DA DIGNI- DADE DA PESSOA HUMANA.}

A grande problemática que cerca o assunto de demissões dos portadores da patologia, seria até onde poderia ir o poder da classe patronal em detrimento dos princípios constitucionais e consequentemente o descarte da mão de obra operária, portadora desse vírus.

Com o passar do tempo, o trabalho foi evoluindo de uma perspectiva penosa do ser humano que exerce o trabalho à verificação de sua essencialidade social. Assim, restou necessária a intervenção do Estado para que fossem resguardados direitos inerentes aos trabalhadores, que muitas vezes haviam sido massacrados pela demanda de grandes produções.

Nesta ceara, originou-se o Direito trabalhista com o simples propósito de regulamentar e regular os contratos laborais e proteger o lado menos favorecido deste meio, o trabalhador. À medida que a sociedade foi se modificando essa "proteção" foi tomando forma de maneira a não retirar a dignidade do ser humano.

É nesta mesma linha de pensamento que a jurisprudência trabalhista vem decidindo em relação a proteção dos direitos dos trabalhadores soropositivos em contraponto com a liberdade patronal de despedimento sem motivo justo.

Vale salientar, que aproximadamente $90 \%$ dos portadores de HIV estão dentro da faixa etária economicamente produtiva, neste caso evidencia-se a importância da aplicabilidade laboral para esse público.

É direito do empregador extinguir o contrato de trabalho unilateralmente, analisando a legislação trabalhista e assuntos acerca de estabilidade, o qual pode impedir de fazê-lo indiscriminadamente. Porém, por outro lado o trabalhador soropositivo, não pode ver limitados seus direitos em razão de seu estado de saúde. Aplicando-se para este caso o princípio da igualdade, princípio este inerente a pessoa humana, portanto não ficando de fora o trabalhador soropositivo, assim como a garantia fundamental a dignidade, sem violação de sua intimidade, não discriminação, como já mencionado anteriormente.

Na decisão em análise, o Juízo de primeiro grau, havia negado o pedido de reintegração ao trabalho, mais indenização por danos morais, por haver sofrido dispensa discriminatória em razão de sua moléstia grave (portador de HIV). 0 reclamante alegou em seu pleito ainda, a possível aplicabilidade da súmula 159 da Organização Internacional do Trabalho, a qual é integrante de nosso ordenamento jurídico, alegando que a referida súmula trata da reabilitação de pessoas deficientes, se enquadrando como tal aos casos da aplicabilidade da súmula explicitada, à medida que precisa da conservação de seu emprego para sua subsistência. Sendo que, o que o limita é a doença. Assim, pediu a reforma da referida decisão como verificado no capítulo anterior.

Após análise dos autos e dos pressupostos de admissibilidade, necessários para o prosseguimento do Recurso, vendo que se tratava que casos análogos a aplicabilidade da súmula 443 do TST, a qual entende discriminatória toda demissão de portadores de doença grave. Admitiu-se assim, o recurso para julgamento, aplicando de maneira eficaz um dos maiores princípios do ordenamento jurídico pátrio, o princípio da dignidade da pessoa humana. 
Vale salientar, que a aplicabilidade da súmula 443 não possui presunção absoluta, caberá ao empregador o ônus de provar que realmente a demissão ocorreu por outro motivo que não seja o estado de saúde do antigo trabalhador.

É neste sentido, tendo por alvo o controle e fiscalização em algumas empresas que não respeitam o tratamento previsto em lei para os soropositivos, com total vigência da referida súmula, pretende-se acabar com as formas discriminatórias de adequação ou a falta de permanência do trabalhador ao local de trabalho.

Com isso, temos um problema público muito falado, porém, pouco modificado na prática.

Decisões mais benéficas aos empregados, devolvendo-lhes a dignidade, pretendendo-se coibir esse tipo de atitude, aplicando a súmula 443 do TST além de políticas inclusivas antes da existência de litígios que sobrecarregam nosso judiciário. Trazendo novamente a pauta, a dignidade de muitas pessoas que foram demitidas de maneira incorreta e sem justificativa plausível, ficando a mercê da própria sorte para compor seus próprios meios de renda.

Ainda a luz do que traz a súmula 443 TRT: "Presume-se discriminatória a despedida de empregado portador do vírus HIV ou de outra doença grave que suscite estigma ou preconceito. Inválido o ato, o empregado tem direito à reintegração no emprego". Por este motivo presumimos que será inválida toda e qualquer demissão caracterizada discriminatória por força de lei.

RECURSO ORDINÁRIO DO RECLAMANTE. DIREITO INDIVIDUAL E PROCESSUAL DO TRABALHO. DISPENSA DISCRIMINATÓRIA. EMPREGADO PORTADOR DE DOENÇA GRAVE. HIV. SÚMULA N ${ }^{\circ} 43$ DO C. TST. Firmou-se a jurisprudência do C. TST no sentido de presumir-se discriminatória a dispensa de empregado portador de doença grave, consoante os termos da Súmula ${ }^{\circ}$ 443. Cumpre dizer que a presunção que decorre da construção jurisprudencial é relativa, podendo ser elidida por prova em sentido contrário, cabendo ao empregador o ônus de demonstrar que o ato de dispensa ocorreu por outra motivação que não a condição de saúde do ex-empregado ou, ainda, que desconhecia a enfermidade. Recurso a que se dá provimento. (TEIXEIRA, 2018, p. 1).

Como podemos perceber já está pacífica a ideia tratada nos tribunais, além de existir vários julgados sobre o assunto, mesmo assim ainda continua ocorrendo no cotidiano de tantos trabalhadores que por vezes só querem seu espaço de trabalho garantido para poder contribuir com o sustento próprio e de seus familiares.

A lei é uma só para todos (levando em consideração os direitos iguais), pois em nossa carta magna já prevê de fato essa igualdade. 0 que nos chama a atenção é que além da Constituição Federal de 1988, existe regulamentação própria para pessoas portadoras de necessidades específicas assim como os portadores do vírus HIV. Mesmo assim não só no meio empresarial em questão, mas de maneira geral, as pessoas em sua grande maioria só se adequam a solicitações estabelecidas em lei por meio de obrigatoriedade, o simples fato de pensar além, por si só, minimizaria uma série de danos a sociedade como um todo.

Não há como seguir de maneira contrária sem antes ferir esse pilar em nossa Carta Magna. É neste diapasão, que a primeira turma do Tribunal Regional do Trabalho da sexta Região vem se posicionando. 
Reforça a ilegalidade da demissão, divergindo com o entendimento do juízo de primeiro grau que proferiu decisão a favor da empresa demandada. Haja vista que além de discriminatória ainda negou a possibilidade de o autor fazer procedimento cirúrgico que estava necessitando no momento:

Relatou que é portador de HIV e também se encontrava com hérnia umbilical no ato da demissão ilegal, tendo inclusive deixado de fazer a cirurgia da hérnia umbilical em razão de a Reclamada ter cancelado o plano de saúde.

Em consequência dos fatos narrados, requereu o reconhecimento do direito à estabilidade no emprego ou indenização substitutiva, bem como indenização por danos morais, por ter sido dispensada por motivo discriminatório. (TEIXEIRA, 2018, p. 3).

O Recurso Ordinário, no processo de número 0000866-87.2016.5.06.0023 primeira turma do Tribunal Regional do Trabalho da sexta região, inicia já com o Relator aclarando, os motivos que o reclamante alega seus direitos.

A relevância da decisão consiste na necessidade de analisar o embasamento para atuação do TRT6 como aplicador dos direitos fundamentais do trabalhador. Tendo por base o princípio da dignidade da pessoa humana - baseada nos direitos de segunda geração, como direitos sociais, econômicos e culturais. Assim como, direitos de titularidade coletiva e com caráter positivo, pois em grande maioria dos casos, exige atuação do Estado. Como já mencionado anteriormente, o relator, em sua decisão, informa ainda que foi negado ao reclamante até o direito de apresentar testemunhas, repudiando tal ato.

Diviso ser aplicável ao caso a Súmula n 443 do C. TST, em cujos precedentes que the deram origem encontram-se casos de empregados portadores de doença grave, não havendo razão para realizar a distinção. O HIV é considerada doença estigmatizante, é grave, e não deixa de acarretar efeitos para os contratos de trabalho, haja vista os afastamentos para tratamento médico e o possível deficit de rendimento, fatos que podem ser considerados pelas empresas para considerar que o empregado portador dessa grave enfermidade não convém ser mantido em seus quadros.

Não por outra razão firmou-se a jurisprudência do C. TST no sentido de presumir-se discriminatória a dispensa de empregado portador de doença grave, consoante os termos da referida súmula, que segue sendo aplicável aos empregados diagnosticados com neoplasia maligna. (TEIXEIRA, 2018, p. 3).

Para o Relator, o que precisava ser aplicado era a mais pura justiça ao caso, devido ao presente fortalecimento da aplicação dos direitos fundamentais.

Assim como no presente caso, o TRT6 já decidiu acerca de temas de alta complexidade como o desrespeito por parte de algumas empresas as garantias fundamentais, tendo por base a restauração de direitos, os quais não podem ser simplesmente ocultados pela massa patronal, quando lhes convir. 


\section{DA LEGITIMIDADE DO TRT6 - OS PRINCÍPIOS CONSTITUCIONAIS APLICADOS EM CONJUNTO AOS PRECEDENTES}

O TRT6 é a maior autoridade jurisdicional trabalhista da região, responsável por dirimir conflitos entre empregados e empregadores os quais tenham sidos levados a rediscussão por via recursal para o referido tribunal. No intuito de sanar alguma "irregularidade" processual.

Com relação aos precedentes, é de extrema necessidade no processo, ligada a valores essenciais do Estado e leva em consideração a segurança jurídica das partes, dando direcionamento para uma uníssona decisão. Constitui peça fundamental de extrema importância para estabilidade das decisões judiciais. Sua aplicabilidade na decisão em análise, foi de extrema relevância, levantando tópicos essenciais para a devolução do direito do Reclamante. Utilizando-se de elementos de caráter individual para conclusão do entendimento.

Na justiça trabalhista pode-se verificar ainda, a questão uma obrigação em uniformizar seu entendimento, para melhor adequação.

Assim o TRT6 não fugiu a regra, em seu entendimento baseou-se em todo teor em decisões proferidas anteriormente, seja pelo mesmo tribunal ou pelo Tribunal Superior do Trabalho.

Mesmo após a imensidão de debates envolvendo o tema, ainda existem dúvidas com relação ao tratamento adequado para o trabalhador soropositivo e por este motivo, é importante salientar que 0 portador do vírus da Imunodeficiência Humana (HIV) terá as mesmas obrigações e os mesmos direitos que os demais trabalhadores.

Além de tratar a todos com a mesma medida, o empregador não poderá em nenhuma hipótese fazer exigências irregulares/ilegais, como a solicitação do exame anti-HIV, não havendo distinção ou qualquer motivo para uma possível discriminação quanto ao estado de saúde do indivíduo, tendo em vista que os exames admissionais e periódicos servem para comprovação de aptidão para função e não para distinção quanto à pessoa.

Há previsão constitucional adequada para o caso em questão no sentido de manter o direito a igualdade de todos. Previsão esta, bem colocada do decurso da decisão proferida:

Como já me manifestei em outra oportunidade, não se pode perder de vista que o constituinte originário trouxe ao centro axiológico do ordenamento jurídico a dignidade da pessoa humana, assim como o valor social do trabalho - colocado aparelhado da livre iniciativa (art. $1^{\circ}$, incisos III e IV, CF/88).

Outrossim, a norma constitucional é expressa em dizer que a ordem econômica é fundada na valorização do trabalho humano e na livre iniciativa, tendo por fim assegurar a todos existência digna, conforme os ditames da justiça social, observados, dentre outros, os princípios da função social da propriedade e da busca do pleno emprego (art. 170, CF/88), estabelecendo, ainda, que a ordem social tem como base o primado do trabalho, e como objetivo o bem-estar e a justiça sociais (art. 193). (TEIXEIRA, 2018, p. 5). 
O tratamento igualitário ainda é previsto por alguns dos princípios do direito do trabalho como o In dúbio pró-operário, que dá a oportunidade de na dúvida o judiciário em suas decisões favorecer a paste mais frágil da relação trabalhista, no caso a pessoa física. Todo tratamento, aplicando a norma mais favoráveis, as quais se adequam ao critério a ser utilizado nos casos que houver mais de uma norma aplicável a situação em potencial. Essa é a discussão da primeira turma do tribunal. A fim de resolver o impasse de maneira mais justa. Além da condição mais benéfica critério que leva o Relator/turma a nunca diminuir as condições mais favoráveis em que se encontra o trabalhador.

O empregador é livre para selecionar seus empregados, porém não poderá usar de condições excludentes como o teste sorológico para condicionar uma possível admissão ou permanência na empresa, até porque não há comprovação médica da impossibilidade do individuo infectado em exercer as atividades laborativas, até que seja provado o contrário.

É exatamente nesse sentido, que a primeira turma do Tribunal Regional do Trabalho vem utilizando os precedentes na deliberação dos casos, como traz à baila o Relator responsável, quando aduz que é entendimento jurisprudencial a presunção de demissão discriminatória a dispensa de empregado portador de doença grave:

Não por outra razão firmou-se a jurisprudência do C. TST no sentido de presumir-se discriminatória a dispensa de empregado portador de doença grave, consoante os termos da referida súmula, que segue sendo aplicável aos empregados diagnosticados com neoplasia maligna. Nesse sentido, colho os seguintes precedentes: (TEIXEIRA, 2018, p. 4).

Aos autos, colacionando sua decisão norteada pela jurisprudência que segue:

Esse entendimento pode ser abstraído do contexto geral de normas do nosso ordenamento jurídico, que entende o trabalhador como indivíduo inserto numa sociedade que vela pelos valores sociais do trabalho, pela dignidade da pessoa humana e pela função social da propriedade (arts. $1^{\circ}$, III e IV e 170, III e VIII, da CF). Não se olvide, outrossim, que faz parte do compromisso do Brasil, também na ordem internacional (Convenção $111 \mathrm{da}$ OIT), o rechaçamento a toda forma de discriminação no âmbito laboral. Na esteira desse raciocínio, foi editada a Súmula 443/TST, que delimita a pacificação da jurisprudência trabalhista neste aspecto, com o seguinte teor: 'Presume-se discriminatória a despedida de empregado portador do vírus HIV ou de outra doença grave que suscite estigma ou preconceito. Inválido o ato, o empregado tem direito à reintegração no emprego' [...] (TRIBUNAL REGIONAL DO TRABALHO 6ª REGIÃO, 2015, n.p.)

Como pode-se notar, a relatoria da primeira turma do TRT6 ${ }^{a}$ Região, toma por base instrumentos jurisprudenciais que já foram resultados de entendimentos em outra seara jurídica.

Importante salientar que não poderá constar como pré-requisito para egresso ou demissão em qualquer empresa a investigação do HIV/AIDS, como parte da avaliação da capacitação para a função assim como teste de gravidez. 
A obrigatoriedade do teste é vedada, segundo as interpretações de dispositivos constitucionais.

Com base na portaria $n^{0} 869$, de 11 de agosto de 1992, é vedado a testagem para detecção do vírus HIV, nos exames pré-admissionais e periódicos dos servidores púbicos.

Outra amostragem na perspectiva jurídica é a que concerne o Ministério do Trabalho e Emprego, a luz da convenção n 111 da Organização Internacional do Trabalho (OIT), a qual proíbe todo e qualquer tipo de discriminação no emprego ou profissão e, paralelamente, a Lei n 9.029/95, que também veda ações discriminatórias e limitativas para efeito de acesso a relação de emprego ou sua manutenção, publicou portaria $n^{\circ} 1.246$, impelindo à prática da solicitação do teste de HIV em casos de efetuados exames médicos pertinentes a relação de trabalho. Essas definições legais, são vertentes concretas, bastante utilizadas na decisão em estudo:

\begin{abstract}
Assim, uma vez aplicável a dicção da Súmula $n^{\circ} 443$ do C. TST e sendo a matéria relativa à discriminação na dispensa eminentemente fática e, portanto relacionada, aos aspectos processuais de distribuição do ônus da prova, presume-se discriminatória a dispensa, presunção essa que sequer pôde ser confrontada com a prova pré-constituída nos autos, que somente confirma os fatos narrados na inicial, isto é, o diagnóstico com HIV em diversos atestados médicos e o afastamento para gozo de benefício previdenciário (ID. 543cbae) com alta em 12.12.2015 e a dispensa injusta logo em seguida em 2.2.2016.

Observe-se que o fato de o afastamento concedido pelo INSS ter sido com base no código 31, sem a comprovação de nexo de causalidade entre a enfermidade e o labor, é irrelevante para a solução do caso presente, em que não se está a discutir a estabilidade do art. 118 da Lei $n^{\circ}$ 8.212/1993, e sim a prática de ato discriminatório previsto na Lei n 9.029/1995, tutelada internacionalmente pela Convenção $n^{\circ} 111$ da OIT, cujo teor é valido transcrever: [...]. (TEIXEIRA, 2018, p. 4).
\end{abstract}

Quanto à comprovação da atitude discriminatória do empregador, sua previsão será juris tantum, ou seja, nos casos que houver discriminação poderá admitir-se prova em contrário. Neste sentido será necessário de munir de provas cabíveis da presente exclusão. 0 que pode ser uma solicitação do exame ou qualquer meio de prova legal que comprove o feito.

Por se tratar de uma doença que não gera riscos de contágio nas relações sociais mediante a atividade laborativas, esse fato por si só já exclui qualquer limitação na aptidão para o trabalho. 0 que existe são áreas não recomendáveis devido ao risco de ferimentos ou de contaminação, nestes casos uma equipe médica deve opinar acerca de determinadas situações específicas.

É vedada a demissão arbitrária do soropositivo, de acordo com o disposto no Art. $7^{\circ}$ da Constituição Federal, como citado pelo Relator. No caso da arbitrariedade o empregado deverá procurar o poder judiciário e garantir seus direitos.

No caso das faltas justificadas ao médico se empregará a mesma postura no que diz respeito à lei, nem tampouco deve haver demissão durante licença médica. Com efeito, revivendo o que trata a Súmula do TST 443, presume-se discriminatória a despedida de empregado portador do vírus HIV ou de outra doença grave que suscite estigma ou preconceito. Inválido o ato, o empregado tem direito à reintegração no emprego. 
No que se pode verificar um dos principais papéis dos precedentes aplicados ao caso, é exatamente manter e fortalecer o papel da empresa em ofertar possibilidades humanamente iguais para a subsistência do trabalhador de maneira geral, além de produzir mudanças positivas no funcionamento psicológico e social do indivíduo, obtendo práticas integrativas no meio, gerando crescimento pessoal e principalmente social.

Indivíduos que trabalham, que podem contribuir para o próprio sustento e de sua família de uma maneira ou de outra, esse bem-estar em sentir-se útil, será refletido em sua saúde, além das estatísticas que possivelmente mostrarão menos um ser humano a mercê de uma sociedade excludente. Sem contar com o fator social que possibilitará crescimento para as empresas que terão em sua maioria funcionários aptos a mostrar suas habilidades laborativas e a gratidão pela oportunidade de poder contribuir como cidadãos ativos e comuns que são.

Em todos os parâmetros se pode notar as garantias destinadas ao empregado, mesmo que sem contrato assinado, com as características exigíveis para configuração de vínculo empregatício.

\section{DAS SANÇÕES APLICADAS NA DECISÃO DO TRT6 - ADEQUAÇ̃̃O DOS PRINCÍPIOS DA INDIVI- DUALIDADE, DA INVIOLABILIDADE À INTIMIDADE, DA PRIVACIDADE, DA HONRA, E DA IMAGEM}

A primeira turma do TRT6, com base em todo arca bolso teórico vai achar dados acerca do tema e decidir de maneira acertada, reintegrando o trabalhador aos seus postos de serviço, devolvendo a eles a possibilidade de mostrar ao meio em que vive que é capaz de superar as dificuldades mesmo sendo portador de um vírus tão degradante, como é o caso do HIV.

Ocorre que, alguns administradores acabam tentando esconder, "maquiando" dados dos desligamentos, de forma a fraudar em seus documentos a real causa da dispensa de alguns empregados.

Assim, o empregado poderá retornar ao seu campo laboral e no caso contrário, os danos emocionais sofridos no decurso do processo da demissão injusta, poderá arguir os danos morais:

Tal circunstância, por certo, causou ao empregado abalo moral, especialmente considerando que vivenciava momento de fragilidade em face da doença de notória gravidade que a acometeu e dos efeitos dela decorrentes.

Assim, caracterizado o dano moral decorrente da forma como realizada a dispensa do empregado, devido o pagamento de indenização, pela primeira reclamada, com fundamento nos artigos $5^{\circ}$, incisos V e X, da Constituição Federal, e 186 e 927, ambos do Código Civil. (TEIXEIRA, 2018, p. 6).

Algumas pesquisas realizadas em anos anteriores, comprovaram que cerca de $90 \%$ das pessoas contaminadas com o vírus, encontravam-se na faixa etária com capacidade para integrar a vida econômica e socialmente ativa. Após estudos como esse pode-se notar que tais assuntos tomam tamanha proporção e que a decisão de reintegração ao trabalho acaba sendo a mais acertada. 
Além do mais, tendo em vista a parcela de contribuição social que os soropositivos dariam se devidamente incluídos ao mercado de trabalho e o contrário de igual maneira poderia ocorrer no caso da não inclusão desses indivíduos economicamente ativos, de modo a serem obrigados a permanecer parados de suas atividades laborais, seria prejudicial as contas do Estado.

Dessa forma, o valor dos danos morais acaba sendo aplicado de maneira punitiva ao empregador que agir em desconformidade legal.

\begin{abstract}
Além do caráter punitivo da indenização, cumprindo seu propósito pedagógico, deve ainda atender aos reclamos compensatórios, considerada a avaliação precisa em torno do grau de culpa do ofensor e sua capacidade econômica, não podendo esta, entretanto, esvaziar seu dever de minorar o sofrimento da vítima.

À vista disso, é que o valor da indenização não pode irrisório a ponto de não reprimir o ofensor na prática de novos atos atentatórios à moral de outrem, nem tão excessivo de maneira a promover o enriquecimento sem causa da parte adversa.

No caso em comento, considerando a gravidade e a extensão do dano causado, mas, sobretudo, o porte da empresa, fixo a indenização por danos morais em $\mathrm{R} \$ 10.000,00$ (dez mil reais), a ser atualizado na forma da Súmula nº 439 do C. TST. (TEIXEIRA, 2018, p. 8).
\end{abstract}

A inserção do soropositivo nas empresas, traz vários benefícios e fará ambos os lados desta relação de crescer. Assim que os Relatores fixam seu entendimento.

0 fato de o empregador rescindir o contrato de trabalho pelo simples término do contrato não configura a discriminação, o que caracteriza o desrespeito é exatamente a dispensa do empregado após o conhecimento do empregador.

Da mesma forma se olharmos por outra perspectiva teremos exatamente a inversão da situação acima relacionada, onde o empregador conhece o empregado que por sua vez é portador do vírus e não o despede.

Como se pode verificar, as várias determinações judiciais já existentes, nelas amplia-se o conceito de que além da irregularidade do ato demissional e da postura equivocada do empregador, a empresa muitas vezes também sai perdendo.

Nessa perspectiva, o Desembargador Relator profere sua decisão no caso em apreço, imputando as medidas sancionatórias cabíveis e restituindo o autor/empregado os direitos a ele inerentes.

Ante o exposto, DOU PROVIMENTO ao recurso ordinário do reclamante para, julgando parcialmente procedentes os pedidos formulados na reclamação, declarar nula a dispensa, condenando à primeira reclamada a:

a) reintegração na função para a qual fora contratado, com ressarcimento integral de todo o período de afastamento, mediante pagamento das remunerações devidas, corrigidas monetariamente e acrescidas de juros legais, além do cancelamento da baixa da CTPS, após o prazo de cinco dias do trânsito em julgado desta decisão, sob pena de pagamento de multa diária de $\mathrm{R} \$ 50,00$ (cinquenta reais) pelo descumprimento de obrigação de fazer, com fundamento no art. 537 do Código de Processo Civil; 
b) indenização por danos morais no valor de R\$10.000,00 (dez mil reais), atualizados na forma da Súmula nº 439 do C. TST.

À condenação arbitro o valor de R\$20.000,00 (vinte mil reais) e inverto o ônus das custas ora fixadas em $\mathrm{R} \$ 400,00$ (quatrocentos reais). Autoriza-se a dedução dos valores rescisórios pagos, sob pena de enriquecimento sem causa do autor. (TEIXEIRA, 2018, p. 7).

Assim, concluindo que a demissão em questão foi realmente discriminatória, portanto, fora dos padrões exigidos por lei para aplicação dos casos análogos. E consequentemente, ao demitir empregados que passam por tantos problemas, que querem ao menos manter sua dignidade e se manter bem em seus postos de trabalho, perdem profissionais exemplares que de uma forma ou de outra podem se destacar na empresa sendo agradecidos por tal oportunidade.

\section{CONSIDERAÇÕES FINAIS}

Diante dos argumentos acima relacionados, se pode notar que o entendimento do Tribunal Regional do Trabalho da $6^{a}$ Região, não foge a regra geral nacional. Existe um entendimento (precedentes) predominante, tanto na esfera legislativa, quanto no judiciário, é no sentido de coibir a prática de condutas totalmente discriminatórias, como a demissão desmotivada de empregado acometidos pelo vírus HIV, que por sua vez ainda mantém condições laborativas, estando apto ao mercado de trabalho.

Vale salientar, que embora a maioria da doutrina e jurisprudência entenda que a demissão de empregado soropositivo, caracteriza conduta arbitrária e discriminatória, gerando direito a reintegração ao empregado ou ainda o pagamento de indenização, existem aqueles que sustentam que pode ser válida a dispensa do portador do vírus, alegando que ainda inexiste tal documento no ordenamento jurídico que garanta o emprego ao trabalhador soropositivo. Mas como já exposto, contra este tipo de argumentação a doutrina e da jurisprudência utilizadas para a decisão acertada da primeira turma do TRT6, definem que também por analogia, existirá a nulidade do ato de dispensa arbitrária e no caso em estudo, discriminatória.

Por este motivo a reintegração do empregado encontra o devido amparo legal, considerando que de alguma forma existirá meios probantes da demissão/tratamento injustificados.

Sabe-se que de maneira geral não é de conhecimento de todos tais ações vexatórias passadas por esses empregados, é por este motivo que quanto mais for exporto essa problemática e trabalhada em conjunto, analisando decisões de outros tribunais, será possível uma mudança de postura e conseguir-se-á resultados equiparados ao que determina a lei. Esse seria o objetivo principal da preocupação que tem os Relatores na tomada de suas decisões. 


\section{REFERÊNCIAS}

MESQUITA, Denis. Site Teixeira Fortes advogados associados. 2016. Disponível em: https://www. fortes.adv.br/pt-BR/conteudo/artigos-e-noticias/406/sumula-443-do-tst-determina-regras-para-adispensa-de-empregado-acometido-por-doenca-grave.aspx. Acesso em: 30 ago. 2017.

CÔRTES, Lourdes. TST.Jus. 2015. Disponível em: http://www.tst.jus.br/noticias/-/asset_ publisher/89Dk/content/trabalhador-que-alegava-ter-sido-demitido-por-ser-soropositivo-nao-conseguecomprovar-discriminacao. Acesso em: 20 out. 2017.

METALÚGICOS, Sindicato do ABC. CNM CUT, 2008. Disponível em: http://www.cnmcut.org.br/ conteudo/direito-governo-tem-atendimento-para-trabalhador-soropositivo. Acesso em: 20 out. 2017.

MORAES, Alexandre de. Direito constitucional. 8. ed. São Paulo: Editora Atlas S. A., 2000.

SANCHES, Vanessa. Tribuna do Pará. 2003. Disponível em: http://www.tribunapr.com.br/noticias/demissaode-empregado-soropositivo-despedida-discriminatoria-ou-direito-potestativo. Acesso em: 19 set. 2017.

MORAES, Alexandre de. Direitos humanos fundamentais. São Paulo: editora Atlas, 2007. p. 46-47.

OSHO. 2017. Disponível em: http://www.osho.com/pt/highlights-of-oshos-world/aids/.

Acesso em: 20 set. 2017.

PINHEIRO, Aline. Consultor Jurídico. 2013. Disponível em: http://www.conjur.com.br/2013-out-03/ preconceito-colegas-trabalho-nao-justifica-demissao-funcionario-hiv. Acesso em: 20 out. 2017.

TRABALHISTA, guia. 2016. Disponível em http://www.guiatrabalhista.com.br/guia/soropositivo.htm. Acesso em: 31 out. 2017.

ORG. Trabalhista. 2006. soropositivo.org. Disponível em: https://soropositivo.org/2014/06/06/adiscriminacao-de-soropositivos-no-mercado-de-trabalho/. Acesso em: 31 out. 2017.

Tribunal Regional do Trabalho 6a Região. 2015. Disponível em: https://trt-6.jusbrasil.com.br/ jurisprudencia/418762617/recurso-ordinario-ro-101379020125060143. Acesso em: 8 nov. 2018.

Tribunal Regional do Trabalho 6a Região. Disponível em: https://trt-6.jusbrasil.com.br/ jurisprudencia/631625351/recurso-ordinario-ro-8668720165060023/inteiro-teor-631625369. Acesso em: 11 nov. 2018. 
BRASIL. Lei n⿳0 12.984, de 2 de jun. de 2014.

Crimes de discriminação dos portadores do vírus

HIV, Brasília, DF, jun. 2014

TEIXEIRA, Sergio Torres. Voto do Relator no NPU 0000866-87.2016.5.06.0023. RECIFE:PJE/TRT6R, 2018, ID no 988ae42, p. 1-4.

\section{Como citar este artigo:}

ROMEO, Andrea. Lo special account del fenomeno religioso nel dibattito nordamericano. Argumenta Journal Law, Jacarezinho - PR, Brasil, n. 29., 2018, p. 15-48. DOI: $10.17564 / 2316-3828.2018 v 7 n 1 p 13-24$

1 Aluna do $10^{\circ}$ período noite, curso de Direito - FACIPE. E-mail: gabrielacarvalho.jus@gmail.com

2 Doutor e Mestre em Teoria do Direito - UFPE; Especialista em Direito Público e Relações Sociais e em Comércio Exterior - UFPE; Professor titular da Faculdade Integrada de Pernambuco - FACIPE; Advogado Parecerista e Consultor Jurídico. E-mail: jclaudio2802@gmail.com

\section{(9) (1) (2)}

Este artigo é licenciado na modalidade acesso abertosob a Atribuição-Compartilhalgual CC BY-SA

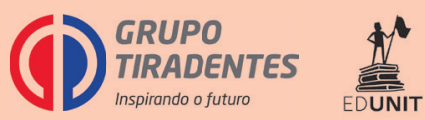


